DOI https://doi.org/10.18551/rjoas.2018-04.19

\title{
A LONG, WINDING AND STEEP ROAD FOR COLLABORATIVE GOVERNANCE IN INDONESIA
}

\author{
Mukhlis M.*, PhD student \\ Government Studies, Faculty of Social and Political Sciences, Padjadjaran University, \\ Indonesia
}

Nazsir N., Rahmatunnisa M., Yuningsih Y., Neneng, Lecturers

Faculty of Social and Political Sciences, Padjadjaran University, Indonesia

*E-mail: maulanamukhlis1978@gmail.com

\begin{abstract}
This paper discusses whether collaborative governance always has positive impacts for inclusive policy-making processes and it also has positive effects on performance, success, and sustainability of policies as argued by its supporters? This paper argues that the argument is not always correct. Although collaborative governance has the potential impact to produce creative problem solving through consensus of parties involved and to create public value and innovation, the concept has also the opportunity to be hampered and thus cannot achieve the expected positive outcomes, due to several challenges and/or obstacles.
\end{abstract}

\section{KEY WORDS}

Collaborative governance, government, Indonesia, policy.

In the development of contemporary governance, the idea of collaborative governance emerges as an important and ideal approach in encouraging the optimization of governance and public policy processes. The idea of collaborative governance comes like a "cure" which is capable to heal various pathologies of policies, either from the politicization of regulation, enlargment and constraint of budget, or the failure of policy implementation (Ansell and Gash, 2007). More explicitly Kallis, Kiparsky and Norgaard (2009) say that collaborative governance is an adaptive management in order to ensure the implementation of a government program, while Sorensen and Torfing (2012) argue that the collaborative governance is a new idea and a practical innovation as a force or power in public sector implementation and as a trigger for better policy making process.

Empirical studies show the benefits and positive impacts of collaborative governance ${ }^{1}$ where collaborative governance is an ideal approach to improving the quality of governance, public service delivery, and public policy performance amid government constraints on resource capacity, the source of funding and networks. Several findings on empirical studies also show that collaborative governance is often associated with good outputs and outcomes. The use of collaborative governance can increase the political legitimacy and the level of public trust significantly to the performance of government. In addition, some of the existing research found that there is still absent of any refutation or explanation of weaknesses of the idea of collaborative governance because they only explain the lack of effectiveness of the collaborative process ${ }^{2}$.

\footnotetext{
${ }^{1}$ For example the application of collaborative governance in the program of water supply in California (Judith E. Innes, et al, 2006); in water resources management policy in Mexico (Sergio Graf Montero, 2006); policy on improving people's welfare in Korea (Sunhyuk Kim, 2010); in the forest rescue program in North Quensland (George R. Sranko, 2011); in labor protection policy (Nidhi Vij, 2011); in a low carbon tourism program (Heather Zeppel, 2012); in a sustainable city achievement policy in Western Australia (Margaret Gollagher and Janette Hartz-Karp, 2013); in the development of health and education in West Java (Jatti Indriati, 2015); and collaboration in disaster management in Yogyakarta (Muchammad Zaenuri, 2016)

${ }^{2}$ See, for example, the effectiveness of collaboration in establishing minimum wages in Bandung (Elisa Susanti, 2016), and the findings of the effectiveness of collaboration in the management of international migrant workers in Yogyakarta (Izzul Fatchu Reza, 2014).
} 
The process of governance and public policy using collaborative governance can be characterized by six elements, namely the initial role of the government, the participation of non-state actors, collaborative decision making, formal arrangement, consensus building, and common issues on policy or public services (Ansell and Gash, 2007). These six characteristics of collaborative governance are also part of the principles of good governance. According to Davis and Keating (2000), the concept of good governance describes how the system of governance takes place, referring to a broader range of roles, not just the government role but also the role of non-governmental organizations and civil society. This means that the interaction of actors (government and non-government organizations) in collaboration will contribute to the realization of good governance.

Similarly, the definition of collaborative governance is explained by Balogh, et al. (2011) where collaborative governance is not only limited to government and nongovernment stakeholders but it is also formed by multipartner governance which are private sector, community and society built by the synergy of stakeholder role in the hybrid plan arrangement as well as co-operation between public private social-private. Balogh, et al., (2011: 2) say that:

"the processes and structures of public policy decision making and management that engage people constructively across the boundaries of public agencies, levels of government, and/or the public, private and civic spheres in order to carry out a public purpose that could not otherwise be accomplished".

Meanwhile, Robertson and Choi (in Kumorotomo, 2013) define the idea of collaborative governance as a collective and egalitarian process where every participant in the idea has substantial authority in decision making and where every stakeholder has equal opportunity to reflect on his/her aspirations in the process. The concept becomes a written rule that each collaborating party has the same position and opportunity in the process of taking and executing public policies.

Dwiyanto (2011: 251) explains in detail that in collaborative cooperation there are vision, goals, strategies, and activities among parties. All parties are independent, have the authority to make decisions independently and have the authority to manage their organizations, although they are subjects to collective agreements. In line with Diwyanto's (2011) definition, Sink (in Purwanti, 2016) describes collaborative processes where organizations have an interest in a particular problem, trying to find a commonly defined solution which can not be achieved independently. Therefore collaboration also means the choice of strategy to accelerate the achievement of interests or goals.

The Failure of Policy: A Case Study. Empirically, the application of collaborative governance in various countries and regions in Indonesia has been very much done in the practice of a particular policy such as the policy of moving the capital governmental city of Lampung Province. Although, the policy was not directly claimed using the collaborative governance approach, as outlined by Ansell and Gash (2007), the policy of moving the capital government area of Lampung Province is an example of an activity that refers to the criteria of collaborative governance characterized by; first is the initial role of the government (the initial idea was originated from Lampung Governor), second is the inclusion of non-state actors (the involvement of private parties and communities), third is the joint decision-making processes (role-sharing arranged in master plan documents), fourth is the formal organization (establishment of an official forum called the Planning Coordination Team and the Area Management Board), fifth is the achievement of a collective consensus between the parties (the issuance of Local Regulation Number 2, year 2013 on the Development of Lampung New Town as a legal umbrella), and sixth is there is a policy issue collaborated (i.e. the policy of moving the capital government area of Lampung Province).

Since the formulation process and implementation of the policy on moving the capital governmental city of Lampung Province, there were several activities which can be associated to the idea of Emerson (2012), referring to the use of collaborative governance. According to Emerson (in Ulibarri, 2015), the policy process where there is an interaction among parties resulting outputs, agreements, and actions, is the core process and the main component of the collaborative framework which he calls it as the dynamics of collaboration. 
In addition to reviewing the collaborative process and interaction between collaborators, the aspect of output, the form of consensus, and collaborative actions are important elements in the dynamics of the collaboration.

In another perspective, Sangkala (2012) considers that one important feature of responsive and collaborative governance is the involvement of actors outside the state. The collaborative relationships among government, private sector and community under responsive and collaborative governance are built on the principle of democracy that emphasizes on the values of equality, freedom of cooperation, and freedom to express ideas and thoughts about what are considered important in supporting the success of public policies and services. In this context, the government positions the public and private sectors as the owner of the government because they are considered having capability to work together in achieving development (Sangkala, 2012).

By having a highly dynamic process ${ }^{3}$, the implementation of policy to move the capital governmental city of Lampung Province which was started in 2010 with the process of moving until the year of 2032 under the total investment of 3.1 trillion rupiah is implemented smoothly. During the moving process, the existence of the formal forum which is the Area Management Board under government regulation number 2, Year 2013, and cooperation with other parties that have been established during the period of $2010-2014$ have proved to be a driver of policy implementation process. The ongoing implementation process of the policy in the period of $2010-2014$ has been changed at the end of 2014 when there was a change of Governor of Lampung in June 2, 2014. Due to limited local budget, the implementation of the five-year on going policy was stopped by the new elected Governor of Lampung.

The case of termination of the policy on moving the capital governmental city of Lampung Province becomes an interesting case. The collaborative governance approach, which is theoretically considered to be a prominent strategy in facing politicization of regulation, swelling and constraints on budgets, as well as the failure of implementation, still cannot be guaranteed for the policy sustainability. In other words, the theory of collaborative governance is an ideal concept claimed by its proponents so that the concept is always associated with good outputs and outcomes, but it is not something smooth in Indonesia; at least in the case of moving the capital governmental city of Lampung Province.

The Diversity Scope of Collaborative Governance. Collaborative governance has a wide range of scopes, for example Booher (2004) and Zadek (2006) focus on the importance of components or elements of collaboration; Huxam and Vangen (2008) focuses on the stages and terms of successful collaboration; Linden (2002) offers a model to evaluate collaborations, as well as Balogh (2011) and Ansell and Gash (2007) propose models or designs of the process of collaborative governance.

In the scope of the components/elements in the collaboration, Booher (2004: 34) proposes collaborative governance in four key components of collaboration with final result to achieve outcomes. Booher (2010) says that:

"Four of the most important in collaborative governance: public policy consensus building, community visioning, consensus rule making, and collaborative network structures. They all reflect key similarities: emphasis on diversity and interdependence, processes that support dialogue and deliberation, the buildingof trustand ongoing capacity to collaborate in the face of continuing uncertainty and change, and the search for solutions that embody good outcomes for the public"

While Zadek (2006) discussed the elements of collaborative governance as follows:

"Collaborative governance life cycles have two key element or phases. First, the design of public policy increasingly involves business and civil society inputs, including specialized knowledge and crucially, lobbying to secure specific outcomes. Second, the implementation of public policy often requires the explicit support of non-state actors in terms of resources

\footnotetext{
${ }^{3}$ For example, the replacement of the capital governental city location from Natar to Jati Agung due to incompatibility between the provincial government of Lampung with PTPN VII, the replacement of the head of the new city management agency, and the change of potential investors from Malaysia and Korea to Lippo Group.
} 
and implementations pathways. With the growing importance of multiple actors during the implementation phase, their leverage also tends to increase over policy design".

Zadek's above statement shows that collaborative governance consists of two important elements: collaboration design and collaborative implementation. Design in collaborative governance is an activity in a policy in which there is involvement of private sector and civil society besides state actors (state), as part of its authority. Stages in the design of collaboration include understanding and lobbying in order to produce specific outcomes. The second element is the implementation of collaboration which also involves the various sectors.

In the scope of stages, Huxam and Vengen (in Wanna, 2008) put forward the stages of collaboration in seven perspectives. All stages are also called as the prerequisite for the success of collaboration, namely, (a) managing aims, as the initial stages of collaboration, (b) managing power, as balancing the power among stakeholders, (c) managing trust, as building trust among stakeholders, (d) managing ambiguity and complexity, as the clarity of the role of stakeholder involvement in collaboration, (e) managing collaborative dynamics, as managing the dynamics of collaboration, ( $f$ ) managing leadership media, as the awareness that the leadership is not the party to always have, and (g) managing leadership activities where there needs a leadership role to ensure the continuity of collaboration.

Meanwhile, Linden (2002) explains that collaboration will work if its implementation fits within the framework of collaboration. He outlines the collaborative framework as follows: (1) the basic are in place, (2) the principal have open trusting relationship with one another, (3) the stakes are high, (4) the participans include a constituency for collaboration, and 5) the leadership fellow collaborative principles. These five theoritically require the existence of trust and open relationships among stakeholders involved in collaboration, stakeholder involvement is not only in the formulation of the agenda but also in the implementation, and the existence of high leadership support as an important element in the principle of collaboration. One important aspect is the basic clarity on the need for collaboration.

Henton (in Susanti, 2016) proposes a model for evaluating collaboration using six aspects: (1) a representative, requiring various ideas from the community to achieve a discussion process; (2) deliberation, defined by a mutually respectful discussion among stakeholders that will result in the exchange of argument so that all arguments must be heard. Differences in point of views should be respected and understood to obtain the same understanding: (3) concrete ideas, is an approach to bring discussion into specific problem and the decision to solve the problem; (4) ideas taken seriously, this is where the involvement of the public must be ensured to be useful for the formulation of policies; (5) sustainable collaborative partnerships, which occurs when the process of collaboration can take place continously in a formal forum established for consultation and decision making; (6) tied to implementation, this is where the outcome of the agreed decision can be implemented.

Several scopes above provide an answer to the definition of collaborative governance. The complexity of answers in general can explain that collaboration is a form of cooperation (O'Flynn and Wanna, 2008); thus, collaborative governance is the process and structure in public policy, involving actors constructively coming from different levels, both at the administrative level and/or agency public, private institutions, and civil society in order to achieve common public goals.

Why Collaborative Governance. The argument underlying the importance of collaborative governance is that governments face internal and external challenges in governance and public policy processes. Internally, the government will not be able to perform the optimal functions of the government if the government only relies on the ability of self-owned resources. A study by Goldsmith and Eggers (2004) shows that the government in overcoming public problems does not always have enough resources. Therefore, there is the need for the governement to make cooperation among parties due to limited in order to implement the project plan and program activities. This internal situation is also exacerbated by the high level of sectoral ego which occurs in most of the public institutions. Thus, the 
right solution to overcome the problem of structural and sectoral-egos is through collaboration (Killian, 2012).

Collaborative governance is needed due to the lack of synchronization and coordination in handling cases caused by weak of networking and cooperation among institutions (Gray, 1989). In Gray's perspective, collaboration is a union of appreciation, and/or material resources, such as information, money, labor, and other resources from two or more stakeholders which are considered to have capability to solve problems which cannot be handled by individual party. As a new breakthrough in the study of policy making, the concept of collaborative governance has been able to bring a progress to the policy making process which is different with mainstream approaches which are only understood as a technocratic problem. Instead, the collaborative governance is the result of interaction and dialogue among parties, influencing each other.

Externally, there is also the fact that the policy environment outside the government is constantly changing and dynamically shifting. The changes or shifts in the policy environment could be in the form of an increasingly widespread issues in the direction of abnormal, the form and the number of rising policy actors, the capacity of the actors outside the government, and the wider community's responses or initiatives (Sudarmo, 2009). It is not an exaggeration if then O'Leary (2014) makes a collaborative governance as the most important choice for building a future public policy in a country.

Ansell and Gash (2007) assert that collaborative governance is ultimately the need of a government to formalize the involvement of the parties outside the government in a formal forum in order to achieve common goals through consensus and deliberative agreements in response to the failure of the downstream of policy implementation, to high costs, and to politicization of policy. Ansell and Gash (2007) explain that:

"A governing arrangement where one or more public agencies directly engage nonstate stakeholders in a collective decision-making process that is formal, consensus-oriented, and deliberative and that aims to make or implement public policy or manage public programs or assets".

Challenges of Collaborative Governance. Although collaborative governance has the potential to produce a creative problem solving through consensus of the parties involved, and perhaps even to create public value and innovation. However, the collaborative governance process also has an opportunity to be hampered and the results of the collaborative governance also have the opportunity to not achieve the expected positive outcomes.

Ansell and Gash (2008) provide remarks about the possibility of the emergence of challenges in collaborative governance. They are the problem of time, trust, and interdependence. There is a remark that collaborative governance is a wasting time process because building consensus in particular issue will take time and can not be rushed. Collaborative governance may therefore not be a good strategy for every situation, which the government must make or implement a quick policy.

Regarding trust and interdependence, Ansell and Gash (2007) suggest that collaborative governance should consider the interactive effects of trust and interdepence. For example, in a high conflict situation, it shows low trust and it can then be organized collaboratively if the stakeholders are highly interdependent. Interdependence aspect leads to the desire to participate and develops a commitment to meaningful collaboration. Therefore, it is possible to build trust in high interdependence situations. Conversely, where the position of interdependence is weak, it will be difficult to effectively build trust. If one of stakeholders threatens to defect from the collaboration, then the commitment of all stakeholders may be changed, and this will make it difficult to develop a sense of ownership, understanding, or trust among parties/stakeholders.

Meanwhile, Plotnikof (2015) in the perspective of the role of public manager emphasizes the importance of communication and interaction of actors related to the implicit challenges in collaborative governance, namely social dynamics which is related to the ambiguity and complexity of membership, the tension of relationships among stakeholders, and the dominance of formal power structures. Social dynamics is considered as a major 
challenge in collaborative governance. The ambiguity and complexity of membership is highlighted as an important element that challenges collaboration, because which groups should be involved and which are not involved, will never be a clear and simple entity. Thus, the accuracy of choosing collaborators and the consistency of the facilitation process from public managers are seen as a never-ending relational practice during the collaboration process.

In line with the risks of tension arising from social dynamics, power is also seen as an important challenge in collaborative governance. This means that the formal power structure in the hierarchy does not have to dominate, but it coincides with the power of the ongoing dynamics and social communication. Power in spite of havingv formal authority, resources, and discursive legitimacy, it can be a challenge if it does not dominate in defining roles, meanings, practices and outcomes of the collaboration.

Similar to Plotnikof (2015), the Government of Canada (in Sudarmo, 2009) explains that the potential for the hamper or collapse of collaboration is due to cultural, institutional, and political factors. Associated with cultural factors, collaboration can be failed due to cultural inclination dependence on procedures and not dare to take breakthroughs and risks. Thus, to create an effective collaboration, it requires public servants (especially leaders) to have the skills and willingness to enter into a pragmatically oriented partnership which is results-oriented.

In addition, collaboration on cultural factors can also be failed because it still retains top down by the government when collaborating with others. In other words, there is still dominance of the government, and this does not enforce the agreement based on the prerequisite of cooperation in egalitarian form of collaboration. Collaboration can also be failed if the participation of interest groups and other stakeholders is considered not as primary or not an imporant needed for collaboration so this will end up with the domination of only one party.

From institutional factors, collaboration may be failed due to the tendency of institutions involved in collaboration (especially actors in government) to apply hierarchical structures to other institutions involved in such cooperation or collaboration, such as the emphasis from the head of the region to the offices / agencies who are involved in the collaboration. In line with political factors, collaboration can also be failed because of the lack of innovation of leaders in achieving the complex and contradictory political goals. In addition, other factors that could lead to collaborative failure are changes in agreements, and differences of interests among stakeholders involved.

In collaborative governance, there can be a problem of power imbalance, where the decision-making process may be dominated by the most powerful actors concerning to their interests being addressed. Choi and Robertson (in Susanti, 2016) state that "a common concern about collaborative governance is that, the decision process may still be dominated by the most powerful actors and interests pertinent to the situation being addressed". The problem of such imbalance leads to difficulties in decision making. To overcome this imbalance the key strategy is to develop effective collaborative governance through facilitating decision making among different stakeholders. Choi and Robertson (in Susanti, 2016) state that:

"As the size of the forum increase, howefer, participants are likely to face greater difficulty making collective decision. A key question for those interested in developing effective collaborative governance systems is how to facilitate decisoo-making dinamycs among diverse stakeholders confronting complexs problems"

Further, Choi and Robertson (2011) argue that consensus building process can help to balance the power among stakeholders. Through more resources, information, legitimacy, and/or prestige, it has enough to form a consensus-building process for stakeholders' benefit. Choi and Robertson (in Susanti, 2016) explain that:

"The goal of achieving consensus among participants can help to balance their power, but those with more resources, information, legitimacy, and/or prestige have considerable capacity to shape the consensus-building process in a direction that favors their interests" 
According to Ansell and Gash (2008), Plotnikof (2015), Government of Canada (2009), and Choi and Robertson (2011), there is an evident that although collaborative governance has the potential to produce creative problem solving with consensus building process from the parties involved as well as creating public value and innovation, this process has also the opportunity to be hampered and to not achieve the expected positive outcomes due to the challenges and/or obstacles.

Finding the Complexity of Challenges on Collaborative Governance. The important question related to the case in this paper is whether the challenges or impediments of collaborative governance in the government policy of Lampung Province concerns only aspects of time, trust, dependence, ambiguity, tension, and dominance of formal power structures as revealed by Ansell and Gash (2007) and Plotnikof (2015)? Apparently it is not. The dynamics of collaborative governance in the government policy of Lampung Province resulted in new other challenges or more complex obstacles which lead to three aspects: 1) the rationality of the substance or content of the policy, 2) the political preference or character of the actors, and 3) the emergence of free riders behind the policy.

Conceptually, so far there is no relationship between rationality or quality of policy content and the success of the collaboration process. The collaborative process model presented by Ansell and Gash (2008) with the emphasis on starting condition, institutional design, and facilitative leadership are proved to be highly managerial. The managerial approach is one aspect that makes the content of the policy content to be neglected. In practice, this aspect of policy content becomes one of the determinants of the collaboration process in the government policy on moving the capital government area. Thus, this becomes one of the challenges of collaborative governance that needs to be considered. The willingness of actors to collaborate and public support for policies are strongly influenced by their positive perceptions of content, substance, and rationality of policy objectives.

The story of the dynamics collaboration in the policy on moving the capital governmental city of Lampung Province shows that on of the aspect of background and policy objectives, efforts to move the capital government area of Lampung Province are perceived by the public as a very rational policy. As the capital of provincial government, Bandar Lampung City faces the limited ability to provide maximum public services due to constrained by the condition of government offices where the city is not conducive due to various problems and urban pressure, lack of land to increase or improve government facilities, and there is integrated government office area. For this reason, the policy on moving the capital government area is rational, as well as the assumption where problem on urban issues will increase in the future.

The question is then how is the relationship between rational policy and the challenge of the collaboration process? One of the factors which support the willingness of actors to collaborate is the understanding and agreement on the substance of the policy to be collaborated. The purpose of moving the capital governmental city of Lampung Province is considered as a practical step taken by the government in order to anticipate the urban problem of Bandar Lampung which is predicted to be more acute.

On the other hand, one of the most important debates during the collaboration process in planning is precisely on the content of the policy which is the legal status of a new city as a new place for the capital government which relates to the status of the City Government of Bandar Lampung and the status of the Regency of South Lampung administratively. The problem of administrative status is different from the substantive status directed to the new city as an independent city which is defined by Soegijoko (2005) where it is a city economically and socially which has been able to fulfill its own needs, or at least most of its population, and geographically located in its own territory is quite far from the existing city, and physically separated by non-settlement areas such as agriculture, forest, green lanes or other non-urban areas with a distance of approximately 80 kilometers. While Golany in Soegijoko (2005) states that a new city is a city planned, established and then developed completely over an entirely new territory after a city or other city has grown and developed first. 
In addition to the administrative issue, the interesting debate is about the placement of the location with the assumption that the new capital government area of Lampung Province is planned to be an independent city. Based on various theories, the new self-contained city placement must be at least $+80 \mathrm{~km}$ from the nearest city at the moment. The distance location of the capital government area with the City of Bandar Lampung is currently no more than $25 \mathrm{~km}$. This debate is one of the most frequent reminded by IAP of Lampung Area during the process of collaboration. The administrative and technical policy debates above do not last long, but these substantive issues of administrative and technical eligibility are very dynamic to be debated in the collaborative process, especially at the planning stage.

Moreover, the claim of success of the collaboration process in the policy on moving the capital government city of Lampung Province actually does not necessarily depict reality in the field. The point is that there is a hidden goal or agenda that most interested actors of the collaboration want to achieve. Actors, who are from the outset, have their own argumentation or self-interest using this means of cooperation to realize their hidden agenda. In this context, collaboration in policy is only an instrument used to work out in order to achieve covered purposes.

In this case, the issue of the policy on moving the capital governmental city of Lampung Province - with the support of mutual recognition that the policy is very rational - is the instrument to influence many parties or to make the issue of the policy on moving the capital city of the Lampung Province as a 'magnet' that can be an attraction to cover the hidden economic interests. On the other hand, there is a dissensus where there are some provisions that are not adhered by the collaborators. The reason is because they feel that the provisions are detrimental to their side so that performing opportunistic actions contradict to the agreed consensus.

The empirical illustration of collaboration in sense of the policy on moving the capital city of the Provincial Government of Lampung leads to the understanding that collaboration is considered to be a place to achieve economic interests so that the collaborators have mutual agreement to act. The evidence of mindsets of some collaborators for only economicoriented can be a foundation for them to cooperate.

Empirical findings in the field can then be interpreted as a logical consequence arising from the mindset that only focuses on how to get the goal (instrumental rationality) and not on what should be done. The cooperation of various actors as well as diverse of interests and motivations may be interpreted as absurd or a simple of mandatory from the embodiment of law or government regulation at the central level ${ }^{4}$, but this is possible if there is a common goal rooted in material-economic interests (Craib, 1986) .

There are four categories of interests (political, economic, technical, and administrative), but in fact, the economic interest or economic-oriented remains a selfinterest wrapped by the appearance of technical and administrative motives. For political motive, of course, the end of this motive is economic benefits. The fact is that this situation occurs in the dynamics of collaboration policy on moving the capital governmental city of Lampung Province.

In essence, all parties included in the collaboration forum (even parties outside the forum) in the policy on moving the capital governmental city of Lampung Province have different agenda, motivation, or interests. But, what can be drawn is that they want to achive the same benefit which is the economic benefit. This economic benefit will not be obtained if they neglect the attitude of egoism and sentiment. So the most rational action to take is to collaborate. Thus, collaboration has charateristic to lock and bind each party to gain benefits.

The assumptions of the motive oof economic benefit that they will gain then override the sentiments and antagonisms among the actors. Consequently, they turn into mutual collaboration. In other words, mutual collaboration among stakeholders is intended to jointly enjoy the assumption of economic benefits. The risk, however, is that collaboration is not

\footnotetext{
${ }^{4}$ Some examples of multi-actor cooperation forums as mandatory manifestations, such as the Road Traffic and Transport Forum (established as mandate of Law No. 22 of 1999 on Road Traffic and Transportation) and the Watershed Management Coordination Forum (as mandated by Law No. 41 of 1999 About Forestry).
} 
necessarily based on the willingness or the consciousness of collaborators to be active as part of the awareness of that collaborative governance is an approach to promote government flexibility and as recognition of that public issues are a common affair. Rather, underlying motive is rationality or reason where they will gain the economic benefits.

The story of how each actor uses rationality to gain economic advantage by exploiting the opportunity structure in collaboration leads to what is called the logic of rational choice. The logic of rational choice is a frame of mind that essentially emphasizes on that everything must be measured by efficiency, productivity, fluency, mathematical certainty, as well as profit and loss calculations. It means that rational individuals will always choose the best alternative from the various available alternatives. If in the case that through ostensibly act of collaboration, their interests will be gained greater ratherthan fighting with or opposing other actors, so the choice of the collaboration is best chosen (Green and Shapiro, 1994).

In addition to the agreement and understanding of the policy objectives, other factors that encourage collaboration are incentives. Incentives are deliberately given as an effort to encourage the emergence of participation. Incentives can be in the direct form such as money or goods and also incentives in the form of prestige, pride, and other psychological aspects. In addition to incentives, the assumption of the benefits that collaborators can gain is also an important factor to drive to the continuity of the collaborative process. In this perspective, collaboration is assumed as a way for achieving interests and therefore collaboration is the best choice rather than to compete. The illustration of consensus and economic rationality above in the case of collaborative policy of the government of Lampung Province confirms the truth of the assumption.

Is the motive or interest in the pursuit of the benefits from collaboration prohibited? Certainly, it is not. However, the aspect that needs to receive more attention beside the belief that the interests of collaborators are not mutually negotiable is the equitable distribution of benefits among parties. It should be assured that the benefits gained by collaborators during the process and the outcomes of the collaboration are equally shared. The role of the leader in the ongoing collaborative process is important in order to convince every collaborator in the sense that joint consensus will be linear with mutual benefits as well. Thus, the shared benefit will further strengthen the aspect of trust.

From Olson's (2012) view, incentives are given to those who are willing to realize collective goals or the public interest. This incentive can be used to deviate the benefits of actors which are outside collaborators. In Olson's perspective, they are referred to as free riders who only enjoy the results but do not get additional incentives as a consequence of willingness to realize the collective goals. The more extreme maximizing behavior of free rider phenomenon is when they essentially seek free opportunities internally and externally. Simply, this situation can be likened to the person who is trying to get to the destination without buying a ticket: they enjoy results without working hard.

In this case, this free rider behavior is not a moral issue and it is not prohibited because in the perspective of organizational behavior, it is normal due to the availability of the opportunity to do so. What needs to be considered, however, is not to disrupt the consensus and thwart the collaboration. Olson (2012) adds that free riders do not only appear from the outside, but also emerge from their own collaborators. Collaborators anticipate incentives obediently and abide by the applicable procedures. However, the goals set forth in the collaboration have never been their main concern.

In the empirical explanation of the policy on moving the capital governmental city of Lampung Province, the collaboration is in place due to the understanding of the goals, although there are also economic interests which seems to be hidden. When collaborators cooperate, at the same time, they are also doing tactics by doing dissensus on provisions they deem harming. The practice of free riding, therefore, is not only demonstrated by actors outside the formal forum, but property companies and village heads who do the business of land plots, as well as illegal farmers, collaborators using dissensus to maximize their benefits which they can receive. 


\section{CONCLUSION}

The collaborative governance is actually an ideal approach with a series of formal procedures. Its proponents believe that collaborative governance potentially leads to creative problem solving with consensus from stakeholders and perhaps even also creating public value and innovation. Various collaborative governance challenges are related to time duration, trust, interdependence, ambiguity and complexity of membership, tension of relationships among collaborators, and the dominance of formal power structures which have been understood as factors that could hinder the collaborative governance process.

However, in the Indonesian governance today, the public policy is dominated by perceptions of the interests of individual holders of power; these challenges seem very managerial and procedural. The formal procedure tends to ignore the political dimension, which does not consider the effect of rationality on the content of the policy, undermines the preference of the political economic character of the actors, and denies the risk of free riders who have greater incentives or benefits than the parties involved in the collaboration. The dynamics of collaborative governance in the government policy of moving the capital governmental city of Lampung Province raises challenges or other more complex obstacles.

Therefore, in the perspective of collaborative governance practices in the local government through awareness of the traditional culture of the government where the perception of individual interests of the regional head (especially different political backgrounds) is more dominant than the rationality of the policy. Thus, there seem to be many steep roads to manifest the ideal of collaborative governance in Indonesia.

\section{REFERENCES}

1. Ansell dan Gash. 2007. Collaborative Governance in Theory and Practice. Journal of Public Administration Research and Theory. Published by Oxford University Press.

2. Balogh, Stephen, dkk. 2011. An Integrative Framework for Collaborative Governance. Journal of Public Administration Research and Theory. Published by Oxford University Press.

3. Craib, lan. 1986. Teori-Teori Sosial Modern: Dari Parsons sampai Habermas. Jakarta: Penerbit Rajawali.

4. Green, Donal P. and Shapiro, lan. 1994. Pathologies of Rational Choice Theory: A Critique of Application in Political Science. Yale: Yale University Press.

5. Innes and Booher, J.E., D.E. 2000. Collaborative Dialogue as a Policy Making Strategy. Berkeley: Institute of Urban and Regional Development University of California.

6. Davis, G dan Keating, M. 2000. The Future of Governance Theory. NSW Australia: Allen Unwin.

7. Dwiyanto, Agus. 2011. Manajemen Pelayanan Publik: Peduli, Inklusif, dan Kolaboratif. Yogyakarta: Gajah Mada University Press.

8. Goldsmith, Stephen and Eggers, William D. 2004. Governing by Network. Washington DC: Brookings Institusion Press.

9. Gray, Barbara. 1989. Collaborating: Finding Common Ground for Multiparty Problems. San Francisco, CA: Jossey-Bass.

10. Kallis, Giorgos, dkk. 2009. Collaborative Governance and Adaptive Management. Jurnal of Enviromental Science and Policy. Published by Elsevier.

11. Killian, Erza P.M. 2012. Paradigma dan Problematika Diplomasi Ekonomi Indonesia. Jurnal Global \& Strategis Th. 6, No. 2, Juli-Desember 2012. Surabaya: FISIP Universitas Airlangga.

12. Kumorotomo, Wahyudi, dkk. 2013. Transformasi Pelayanan Jakarta Commuter Line: Studi Tentang Collaborative Governance di Sektor Publik. Yogyakarta: Jurusan Manajemen dan Kebijakan Publik FISIPOL Universitas Gadjah Mada.

13. Linden, Russel M. 2002. Working Acrros Boundaris: Making Collaborative Work In Government and Non Profit Organization. San Fransisco: Joseey Bass. 
14. O’Flynn, Janine and Wanna, John. 2008. Collaborative Governance, A New Era of Public Policy in Australia?. Canberra: The Australian National University

15. O'Leary, Rosemary. 2014. Collaborative Governance in New Zealand: Important Choice Ahead. Published by lan Axford Fellowships dan Public Policy. New Zealand Government.

16. Olson, Mancur, 2012. The Logic of Collective Action: Public Goods and The Theory of Groups 2. Article p. 2. America: Harvard University Press.

17. Plotnikof, Mie. 2015. Challenges of Collaborative Governance: An Organizational Discourse Study of Public Managers' Struggles with Collaboration Across the Daycare Area. PhD Series 26.2015. Copenhagen, Denmark: Copenhegen Business School.

18. Purwanti, Nurul D. 2016. Collaborative Governance (Kebijakan Publik dan Pemerintahan Kolaboratif, Isu-Isu Kontemporer). Yogyakarta: Center for Policy \& Management Studies FISIPOL Universitas Gadjah Mada.

19. Sangkala. 2012. Dimensi-Dimensi Manajemen Publik. Yogyakarta: Penerbit Ombak.

20. Soegijoko, Sugijanto. 2005. Pembangunan Kota Indonesia dalam Abad 21, Pengalaman Pembangunan Perkotaan di Indonesia. Jakarta: Urban and Regional Development Institut (URDI).

21. Sorensen, Eva, dkk. 2012. Collaborative Innovation in The Public Sector. The Public Sector Innovation Journal. Vol 17 (1).

22. Sudarmo. 2009. Elemen-elemen Collaborative Leadership dan Hambatan-Hambatan bagi Pencapaian Efektivitas Collaborrative Governance; Spirit Publik. Jurnal IImu Administrasi Vol. 5, No.2. Surakarta: IImu Administrasi FISIP UNS.

23. Susanti, Elisa. 2016. Kolaborasi Dalam Penetapan Upah Minimum Di Kabupaten Bandung. Disertasi Doktor Ilmu Administrasi Universitas Padjadjaran. Bandung: Program Pascasarjana FISIP Universitas Padjadjaran.

24. Ulibarri, Nicola. 2015. Tracing Process to Performance of Collaborative Governance: A Comparative Case Study of Federal Hydropower Licensing. Journal Political Studies Volume 43 Issue 2.

25. Zadek, Simon. 2006. The Logic of Collaborative Governance: Coorporate Responsibility, Accountability, dan the Social Contract. Working Paper No. 17 Harvard University. 